\title{
HENRY ERNEST STAPLETON
}

$$
\text { I } 878-\text { I } 962
$$

Henry Ernest Stapleton was born at Boroughbridge, Yorkshire, and was educated at Bradford Grammar School and St. John's College, Oxford. He was a scholar of his College and took a first in Chemistry in the Final Honours School of Natural Science in 1899. After a year's research at Cambridge he entered the Indian Education Service, becoming an Inspector of Schools and holding various important academic and administrative appointments. His distinguished career was interrupted by the war; in May I9I 5 he was commissioned in the Indian Army Reserve and in the September following he took a draft to Mesopotamia to join the 24th Punjabis. Almost immediately he was in action at Ctesiphon with Townshend's force and involved in the dramatic retreat to Kut-elAmarah, in November 1915. Kut was besieged by the Turks and in spite of strenuous efforts by the relieving force it had to surrender on 29 April 1916. Being forced to endure the rigours and privations, first of a long siege, then for some two and a half years in a Turkish prison camp, was a testing experience, both morally and physically. But Stapleton possessed three outstanding characteristics of survival value-a fine constitution, a cheerful disposition and a cultured mind. He was already a confirmed oriental scholar and in Asia Minor he turned to good account in study the time on his hands and his restrictions in freedom. After the war, before returning to India, he spent some time in Oxford and settled his family in Jersey. At the end of 1919 , he resumed his career in India, occupying leading positions in education which included the post of Principal of Presidency College, Calcutta, and also that of Special Officer in connection with the opening of Dacca University. He retired from the Indian Education Service in 1933, re-joining his family in Jersey, but returned to India for a spell two years later, to catalogue and advise on the preservation of manuscripts in the library of Hyderabad University. He finally settled in Jersey in 1935 where he raised a fine Jersey herd of cattle and experimented scientifically with the aim of increasing the butter-fat content of their milk. But he also found time to continue and extend his many intellectual interests, reading original papers to Learned Societies, including our own, as shown in the bibliography kindly prepared for us by his friend and collaborator, Dr. G. L. Lewis, of Oxford.

\section{F. H. C. Butler}


We are indebted to Dr. G. J. Whitrow for the following appreciation:

\section{Dr. H. E. Stapleton}

I came to know Stapleton very well during the last seven years of his life. Characteristically, he introduced himself by letter, following a lecture by me to the Society on Hindu mathematics in November 1954 which he had been unable to attend, and he asked if I could throw any light on 'a certain Indian diagram mentioned in Al-Biruni's India'. This led to an exchange of between seventy and eighty letters mainly devoted to the early history of right-angled triangles, Pythagorean numbertriads, and related topics. His interest in these questions derived from his pioneer researches, inspired by the work of Paul Kraus, on the 'Probable Sources of the Numbers on which Jābirian Alchemy was based' (see Bibliography, items I 7 and 20). Stapleton's later researches on Pythagoreanism, which owed something to our correspondence, culminated in a long paper published in Osiris (Bibliography item 24).

Even though I was occasionally inclined to be a little sceptical of some of his ideas, I always found Stapleton a stimulating conversationalist, an enthusiastic correspondent, a generous host and a true friend. His genial farmer-like presence, twinkling eye, and infectious enthusiasm for the history of ancient science will long be missed.

A Bibliography of Papers by the late Henry Ernest Stapleton, M.A., D.Litt., B.Sc. Formerly Professor of Chemistry and Inspector of Schools and Director of Public Instruction, Bengal

I 899

(I) Tetrazoline. By Siegfried Ruhemann and H. E. Stapleton. Transactions of the Chemical Society 75, I I 3 I-I 133 .

I 900

(2) The Formation of Heterocyclic Compounds. By Siegfried Ruhemann and H. E. Stapleton. Transactions of the Chemical Society 77, 239-25 .

(3) Condensation of Ethyl Acetylenedicarboxylate with Bases and $\beta$-Ketonic Esters. By Siegfried Ruhemann and H. E. Stapleton. Transactions of the Chemical Society 77, 804-8 I 0.

(4) Condensation of Phenols with Esters of the Acetylene Series. Part III. Synthesis of Benzo- $\gamma$-pyrone. By Siegfried Ruhemann and H. E. Stapleton. Transactions of the Chemical Society 77, I I 79- I 185.

(5) Sal-Ammoniac: a Study in Primitive Chemistry. Memoirs of the Asiatic Society of Bengal 1, No. 2, 25-42.

(6) Alchemical Equipment in the Eleventh Century, A.D. By H. E. Stapleton and R. F. Azo. Memoirs of the Asiatic Society of Bengal 1, No. 4, 47-70.

Ig Io

(7) An Alchemical Compilation of the Thirteenth Century, A.D. By H. E. Stapleton and R. F. Azo. Memoirs of the Asiatic Society of Bengal, 3 No. 2, 57-94. 
(8) Chemistry in 'Irāq and Persia in the Tenth Century A.D. By H. E. Stapleton, the late R. F. Azo and M. Hidāyat Husain. Memoirs of the Asiatic Society of Bengal 8, No. 6, 3 I 7-4 I 8. (Reviewed by Sarton in Isis I I, I 29-I 34.)

(9) A Find of 182 Silver Coins of Kings of the Husainī and Surī Dynasties from Raipārā, Thāna Dohar, District Dacca, Eastern Bengal. Fournal and Proceedings of the Asiatic Society of Bengal N.S.25, Numismatic Supplement, 5-22.

I93 I

(Io) Arabic Source of Zadith's 'Tabula Chemica'. By H. E. Stapleton and M. Hidāyat Husain. Nature 127, 926 .

(I I) Note on the Arabic MSS. on Alchemy in the Âsafîyah Library, Hyderâbâd (Deccan) India. Archeion 14, 57-6 I .

(12) Report on the Mä' al-Waraqi. By H. E. Stapleton and M. Hidāyat Husain. Archeion 14, 74-75.

1933

(13) Three Arabic Treatises on Alchemy by Muhammad Bin Umail (Ioth Century A.D.). Edition of the Texts by M. Turāb 'Alī; Excursus on the Writings and Date of Ibn Umail with Edition of the Latin Rendering of the $M \vec{a} \cdot$ al-Waraqi by H. E. Stapleton and M. Hidāyat Husain. Memoirs of the Asiatic Society of Bengal 12, No. I, I-2 I 3. (Reviewed by Ruska in Isis 24, 310-342.)

(r4) Further Notes on the Arabic Alchemical Manuscripts in the Libraries of India. Isis 26, I 27-I 3 I.

1949

(15) The Sayings of Hermes Quoted in the $M \bar{a}^{\prime}$ al-Waraqi of Ibn Umail. By H. E. Stapleton, G. L. Lewis and F. Sherwood Taylor. Ambix 3, 69-9o.

(16) The Antiquity of Alchemy. Archives Internationales d'Histoire des Sciences No. 14, 35-38. (Summary of item I 9.)

I $95^{2}$

(I7) Probable Sources of the Numbers on which Jabirian Alchemy was Based. Bulletin of the British Society for the History of Science $\mathbf{r}, 2 \mathrm{I}$ I. (Abstract of paper read at Symposium on Historical Scientific Contacts between East and West, London, I 7 April 1952; for full text see item 20.)

I953

(18) Origin of Short-horned Cattle. Bulletin of the Société Jersiaise 16, 100-102. (Summary of a paper read on 6 September $195^{2}$ at Vienna before Section B-I-d of the IVth International Congress of Anthropological and Ethnological Sciences but not printed in the Actes du IVe Congrès.) 
(19) The Antiquity of Alchemy. Ambix 5, I-43. (Discussed in Chemical Section (Group II) of VIth International Congress of the History of the Sciences, Amsterdam, 14-2 1 August 1950.)

(20) Probable Sources of the Numbers on which Jäbirian Alchemy was based. Archives Internationales d'Histoire des Sciences No. 22, 44-59.

1954

(2 I) The 'Standards' of Alaja Hoyuk. Proceedings of the Twenty-Third International Congress of Orientalists (Cambridge, 2 I-28 August 1954), I39-I II.

$$
1956
$$

(22) The Hand (with its 5 fingers) as the primitive basis of Geometry, Arithmetic and Algebra. Actes du VIIIe Congrès International d'Histoire des Sciences (Florence, 3-9 September 1956), I I03. (Summary of Part II of item 24.)

(23) The Gnomon as a possible link between (a) one type of Mesopotamian Ziggurat and (b) the Magic Square Numbers on which Jäbirian Alchemy was based. Ambix 6, 1-9. (Introductory section of a paper on Pythagoreanism read at VIIth International Congress of the History of the Sciences, Jerusalem, August 1953.)

$195^{8}$
(24) Ancient and Modern Aspects of Pythagoreanism. Osiris 13, 12-53.

1962

(25) Two Alchemical Treatises Attributed to Avicenna. By the late H. E. Stapleton, the late R. F. Azo, the late M. Hidayat Husain and G. L. Lewis. Ambix 10, 4 I-82. 